\title{
A Rare Complication of Legionella
Pneumonia: Sensorineural Hearing Loss*
}

\author{
Legionella Pnömonisinin Nadir Bir Komplikasyonu: Sensörinöral \\ İsitme Kaybı
}

Gözde Kalbaran Kısmet, Oğuzhan Okutan, Hasan Furkan Avcı, Tayfun Çalıskan, Zafer Kartaloğlu

\begin{abstract}
Sensorineural hearing loss, a rare complication in Legionella pneumonia, is said to be attributable to the production of endoctoxin-like substances by Legionella species and their immune-mediated effect. A 43-year-old male patient presented with complaints of fever, chills, wheezing and hearing loss for the past five days. Bilateral widespread ground glass densities and consolidation, including air bronchogram, were detected in a thorax computed tomography. Bilateral moderate sensorineural hearing loss was detected upon a pure audio audiometry. Legionella pneumonia was diagnosed based on the presence of the Legionella antigen in the urine. Clinical and radiological improvement was achieved with fluoroquinolone and corticosteroid treatment. This case is presented to literature as a rare but significant complication of Legionella pneumonia.
\end{abstract}

Key words: Atypical pneumonia, legionella pneumonia, sensorineural hearing loss.

\section{Özet}

Legionella pnömonisinde sensörinöral işitme kaybı nadir bir komplikasyon olup Legionella türlerinin endoktoksin benzeri maddeler üretimi ile bunların immün-aracılı etkisi nedeniyle meydana geldiği düşünülmektedir. Kırk üç yaşında erkek hasta son beş gündür olan ateş, titreme, hırıltı ve işitme kaybı şikayetleri ile başvurdu. Toraks bilgisayarlı tomografisinde bilateral yaygın buzlu cam dansiteleri ve hava bronkogramı içeren konsolidasyonlar saptandı. Saf ses odyometrisinde bilateral orta derecede sensörinöral işitme kaybı tespit edildi. İdrarda Legionella antijeni pozitifliği ile Legionella pnömonisi tanısı konuldu. Florokinolon ve kortikosteroid tedavisi ile klinik ve radyolojik iyileşme gözlendi. Hasta, Legionella pnömonisinin nadir ancak önemli bir komplikasyonu nedeniyle literatür eşliğinde sunuldu.

Anahtar Sözcükler: Atipik pnömoni, legionella pnömonisi, sensörinöral işitme kaybı.
Department of Chest Diseases, University of Health Sciences, Hamidiye Faculty of Medicine, Sultan II. Abdülhamid Han Health Application and Research Center, İstanbul, Turkey Sağlık Bilimleri Üniversitesi, Sultan II.Abdülhamid Han Sağlık
Uygulama ve Araştırma Merkezi, Göğüs Hastalıkları Servisi,
İstanbul

Submitted (Başvuru tarihi): 13.12.2020 Accepted (Kabul tarihi): 19.01.2021

Correspondence (iletişim): Gözde Kalbaran Kısmet, Department of Chest Diseases, University of Health Sciences, Hamidiye Faculty of Medicine, Sultan II. Abdülhamid Han Health Application and Research Center, İstanbul, Turkey

e-mail: gozde468@gmail.com

*This case report was accepted and presented as an Electronic Poster presentation with the presentation number "EP-292" and entitled "Lejyonella pnömonisi'nin nadir bir komplikasyonu: Sensörinöral işitme kaybı" at the 41 st National Congress of TÜSAD on October 26 $29,2019$. 
Legionella pneumophila is an atypical pneumonia agent that proliferates intracellularly, and that is associated with high mortality rates. Legionella pneumonia is frequently encountered in immunocompromised patients (1), with infection occurring through contaminated aerosols and water during recent travel, accommodation in hotels, and during the restoration of water pipes (2-4). Diagnosis can be challenging due to the non-specific clinical and radiological findings, and also the specific laboratory tests that are required $(1,4)$. The most specific tests for diagnosis are cultures and the detection of the Legionella antigen in the urine $(5,6)$. Legionella and Mycoplasma are the two most common factors in atypical community-acquired pneumonia that are known to cause sensorineural hearing loss. Here, we present a clinical case with Legionella pneumonia that experienced the sudden onset of sensorineural hearing loss.

\section{CASE}

A 43-year-old heavy smoking male with no history of chronic disease had undergone cold treatment one week earlier due to the onset of upper respiratory tract symptoms. The patient was referred to our clinic with fever, chills, wheezing and sudden hearing loss for the last five days. A physical examination revealed the general condition of the patient to be good, and he was conscious, oriented and cooperative. The patient's temperature was $37.4{ }^{\circ} \mathrm{C}$; pulse: $91 /$ minute/rhythmic; arterial blood pressure, $97 / 65 \mathrm{mmHg}$; respiratory rate, $20 /$ minute; and $\mathrm{SpO}_{2}$ in room air, 90\%. An aural examination of the respiratory system revealed biphasic rales in the interscapular space and under the bilateral scapula that were more prominent on the left side of the patient, along with icteric sclera and hearing loss. Lymphopenia and anemia was identified in the patient's hemogram, and elevated liver enzymes, lactate dehydrogenase (LDH), creatine kinase $(C K)$, sedimentation and $\mathrm{C}$-reactive protein (CRP) values were identified in routine biochemical tests. A urinalysis revealed erythrocyte + , leukocyte + , urobilinogen ++ , nitrite + , protein + and rich bacteria. As seen in Figure 1, thorax computed tomography showed consolidation with air bronchogram and ground glass opacities, increasing in different locations in both lungs. An ear, nose and throat diseases (ENT) department consultation led to the detection of bilateral moderate sensorineural hearing loss (SNHL) in the audiogram (Figure 3). Hyperbaric oxygen therapy (HBOT) was not considered for the patient after consulting undersea and hyperbaric medicine. Oral prednisolone treatment was started at a dose of $1 \mathrm{mg} / \mathrm{kg}$ under the recommendation of ENT specialists. Atypical pneumonia and autoimmune disease were considered as a preliminary diagnosis based on clinical, radiological and laboratory findings. The patient's viral panel for hepatitis and autoimmune tests were negative; and serological tests for Chlamydia and Mycoplasma were also negative. Levofloxacin treatment was initiated after a positive Legionella antigen urine test. Clinical and radiological improvement was observed in the patient who experienced sudden hearing loss that was thought to be related to legionella pneumonia, after levofloxacin and corticosteroid treatment. Figure $2 \mathrm{a}$ shows the bilateral heterogeneous infiltrative changes in the middle and upper zones on a PA chest radiograph taken before the treatment and in Figure $2 b$ that were observed to regress with treatment.

\section{DISCUSSION}

In general, Legionella species are identified as one of the causative agents in community-acquired pneumonia in patients with chronic lung disease, end stage renal disease, cancer and AIDS and, particularly in patients with T-cell defects and those on steroids $(2,3)$. Other risk factors include smoking and aged over 65 years. The only risk factor in the present case was a 90-pack/year smoking history (2). Patients may present with pulmonary or extrapulmonary symptoms, and Legionella pneumonia can be suspected in the presence of neurological findings (headache, confusion, encephalopathy, etc.), hematuria, hyponatremia, unexplained hypophosphatemia, liver enzymes (LFT), LDH and CK increases in patients with pneumonia (5). Mirroring previous cases reported in literature, our patient also had elevated LFT, LDH and CK. The optimum diagnostic approach is related to the production of the agent in culture. Urine antigen tests are an alternative diagnostic method that are available only for the Legionella pneumophila serogroup 1, and most pneumonias occur in this group (6). Since urine antigen positivity lasts for a long time, this condition can be used for etiology determination. In our case, the diagnosis was made based on urinary antigenuria. 

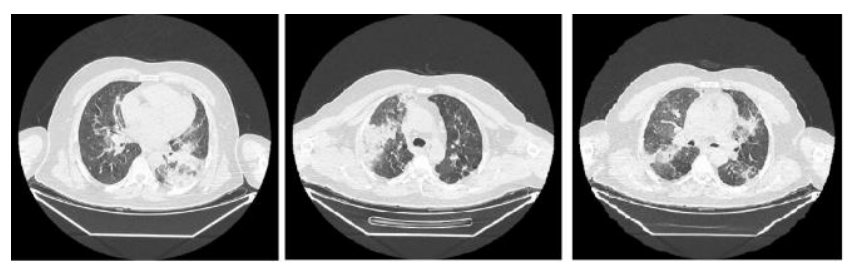

Figure 1: Thorax computed tomography showing consolidation with air bronchogram and ground glass opacity increases in different locations in both lungs
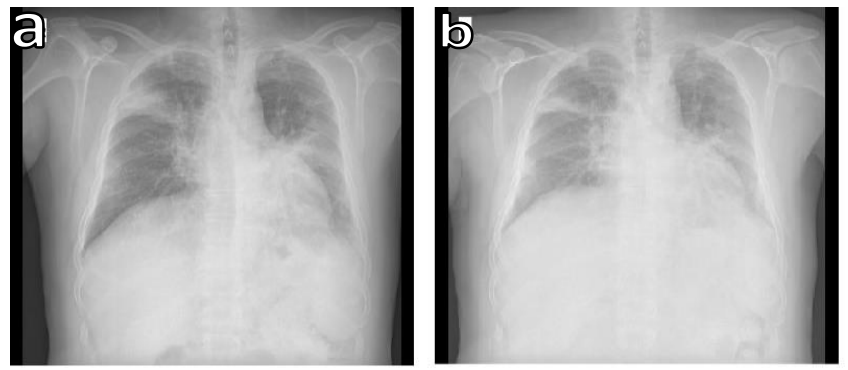

Figure $2 a$ and $b:$ PA chest radiographs of the patient before and after treatment, showing bilateral heterogeneous infiltrative changes in the middle and upper zones on a PA chest radiograph taken before treatment (a) that regressed with treatment (b)

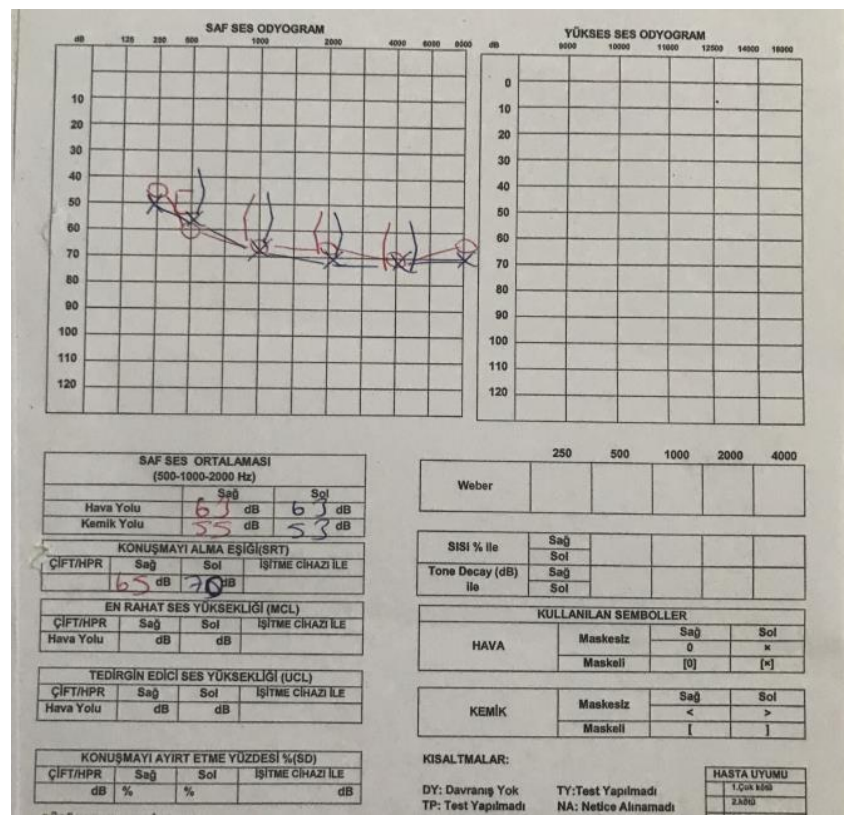

Figure 3: Audiometry showing bilateral moderate sensorineural hearing loss

Legionella pneumonia may present with mild clinical symptoms, with gastrointestinal system and neurological findings, and with multiple organ failure. A review of literature revealed that hearing loss can develop alongside Mycoplasma and Legionella infection (7), with the degree of hearing loss reported in literature being moderate to severe. In our case, the bone conduction hearing threshold mean for the right side and left side were measured as 55 decibels $(\mathrm{dB})$ and 53 decibels $(\mathrm{dB})$ in pure tone audiometry, respectively (Figure 3), meaning bilateral moderate SNHL was detected. Kobayashi et al.
(8) reported a case in which acute bilateral hearing loss emerged as a complication of Mycoplasma Pneumonia infection, and the deafness did not improve despite prednisolone treatment. Morelli et al. (9) first identified the possible link between Legionella and $\mathrm{SNHL}$, reporting on a case of Legionella pneumonia with diffuse brainstem encephalopathy including ataxia and severe bilateral hearing loss in a young male patient. Although the pathogenesis of neurological dysfunction is unclear, the authors hypothesized that the Legionella species had an immune-mediated effect, producing endotoxin-like substances. In another clinical case, transient hearing loss was noted to develop in a patient with Legionella pneumonia after treatment with erythromycin (10). Nolte et al. (11) presented a case with Legionella pneumonia, and suggested that the sudden sensorineural hearing loss may have been associated with infection, and stated that this was the second such case to be reported in literature. In our clinical case, the patient's hearing loss was thought to be related to infection, since the patient had not been treated with antibiotics prior to presentation to our facility. SNHL mostly resolves spontaneously, but as the cause of hearing loss is generally thought to be related to the immune process, patients are commonly treated with systemic corticosteroids. The recovery rate in systemic steroid use varies between 49 and $89 \%$ (12), and the most common treatment is prednisolone at a dose of $1 \mathrm{mg} / \mathrm{kg}$ for 10 days (13). Other treatment options include intratympanic steroid application, vasodilator drugs, hyperbaric oxygen and ozone therapy. HBOT is not the main treatment option for SNHL, being used only as an adjunct therapy approach (14). Since our patient had severe pneumonia, HBOT treatment was not considered so as to avoid any complications. In our case, the hearing loss regressed completely after oral steroid therapy. As in our case, atypical pneumonia factors should be considered in the presence of appropriate clinical, radiological and laboratory findings. Furthermore, if SNHL is accompanied by pneumonia, the possibility of Mycoplasma or Legionella should be kept in mind. Although SNHL is rare, clinicians should be aware of the existence of this potential complication.

\section{CONFLICTS OF INTEREST}

None declared.

\section{AUTHOR CONTRIBUTIONS}

Concept - G.K.K., H.F.A., O.O., T.Ç., Z.K.; Planning and Design - H.F.A., G.K.K., T.Ç., O.O., Z.K.; Supervi- 
sion - Z.K., H.F.A., T.Ç., O.O., G.K.K.; Funding - G.K.K., H.F.A.; Materials - T.Ç., O.O.; Data Collection and/or Processing - G.K.K., O.O.; Analysis and/or Interpretation - Z.K., O.O.; Literature Review - G.K.K., H.F.A.; Writing G.K.K.; Critical Review - T.Ç.

\section{YAZAR KATKILARI}

Fikir - G.K.K., H.F.A., O.O., T.Ç., Z.K.; Tasarım ve Dizayn - H.F.A., G.K.K., T.Ç., O.O., Z.K.; Denetleme - Z.K., H.F.A., T.Ç., O.O., G.K.K.; Kaynaklar - G.K.K., H.F.A.; Malzemeler - T.Ç., O.O.; Veri Toplama ve/veya İşleme G.K.K., O.O.; Analiz ve/veya Yorum - Z.K., O.O.; Literatür Taraması - G.K.K., H.F.A.; Yazıyı Yazan - G.K.K.; Eleştirel İnceleme - T.Ç.

\section{REFERENCES}

1. Mulazimoglu L, Yu VL. Can legionnaires' disease be diagnosed by clinical criteria?: a critical review. Chest 2001; 120:1049-53. [CrossRef]

2. Yu VL. Legionella pneumophila (Legionnaires' disease). In: Mandell GL, Bennett JE, Dolin R(eds): Principles and Practice of Infectious Diseases, 5th ed. Churcill Livingstone, Philadelphia, 2000: 2424-7.

3. Bülbül Y, Özlü T. Erişkinlerde toplumda gelişen pnömoni tanı ve tedavi uzlaşı raporu. Türk Toraks Dergisi 2009; 10 (Ek 9).

4. Marston BJ, Lipman HB, Breiman RF. Surveillance for Legionnaires disease: risk factors for morbidity and mortality. Arch Intern Med 1994; 154: 2417-22. [CrossRef]

5. Stout JE, Yu VL. Legionellosis. New Engl J Med 1997; 337: 682-7. [CrossRef]
6. Den Boer JW, Yzerman EP. Diagnosis of Legionella infection in Legionnaires'disease. Eur J Clin Microbiol Infect Dis $2004 ; 23: 871-8$. [CrossRef]

7. Garcia Berrocal JR, Ramierez-Camacho R, Porteo F, Vargas JA. Role of viral and Mycoplasma pneumoniae infection in idiopathic sudden sensorineural hearing loss. Acta Otolaryngol 2000; 120:835-9. [CrossRef]

8. Nishioka K, Masuda Y, Okada S, Takata N, Tasaka S, Ogura $Y$. Bilateral sensorineural hearing loss associated with Mycoplasma pneumoniae infection. Laryngosope 1987; 97:1203-6. [CrossRef]

9. Morelli N, Battaglia E, Lattuada P: Brainstem involvement in Legionnaires' disease. Infection 2006; 34:49-52. [CrossRef]

10. Meyer RD, Edelstein PH, Kirby BD, Louie MH, Mulligan $\mathrm{ME}$, Morgenstein AA, et al. Legionnaires' disease: unusual clinical and laboratory features. Ann Intern Med 1980; 93:240-3. [CrossRef]

11. Nolte, JE, Altman A, Szyper-Kravitz M, Shoenfeld Y, Zimlichman E. Legionella-induced Sudden Hearing Loss: a Rare Complication. Infection, 2009; 37:377-8. [CrossRef]

12. Chandrasekhar SS. Intratympanic dexamethasone for sudden sensorineural hearing loss: clinical and laboratory evaluation. Otol Neurotol 2001; 22:18- 23. [CrossRef]

13. Conlin AE, Parnes LS. Treatment of sudden sensorineural hearing loss: I. A systematic review. Arch Otolaryngol Head Neck Surg 2007; 133:573-81. [CrossRef]

14. Konstantina G, Fildissis G, Zyga S, Baltopoulos G. The clinical efficacy of hyperbaric oxygen therapy in idiopathic sudden sensorineural hearing loss and tinnitus. Health Sci J 2015; 10:1 